\title{
The Philosophy of \\ Midcentury Corporation Statutes
}

by WILBER G. KATZ

James Parker Hall Professor of Law, The University of Chicago Law School.

Reprinted by permission from Law and Contemporary Problems, published by the Duke University School of Law, Durham, North Carolina. Copyright, 1958, by Duke University.

In the "New Look" title for this symposium, the Editor suggests a tempting figure of speech concerning fashions in corporation laws. He invites contributors to examine the models now on display and to describe what it is that constitutes the "new look." It might be entertaining to see how far one could spin out the fashion-show analogy. (One uninhibited commentator has, indeed, suggested that the contours of the American Bar Association's Model Business Corporation Act make it a seductive invitation to irresponsibility. $\left.{ }^{1}\right)$ My pen, however, is too heavy for such a task; and the Editor has used the term "philosophy" in defining my subject. What is expected from me, I take it, is a discussion of contemporary theories concerning the purposes of corporation statutes and the provisions appropriate for the accomplishment of those purposes. In trying to meet this assignment, it seems most promising to look not for theories embodied in toto in particular statutes, but for theories reflected in various statutes in different degrees and proportions.

The general purpose of incorporation statutes is to

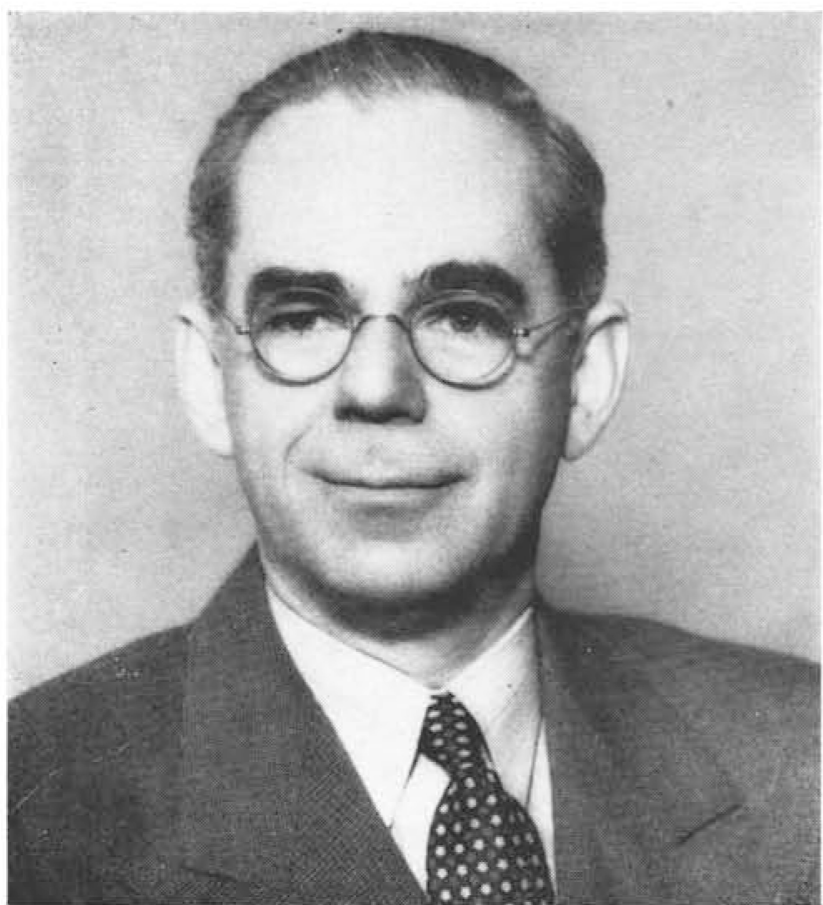

Wilber G. Katz, James Parker Hall Professor of Lau. provide a particular legal mode for the organization of business enterprise. If we are to try to be "philosophical," we must begin at the beginning; we must begin with the concept of business enterprise and the function of the law of business organization. For our purposes, analysis of the concept of enterprise discloses three elements: risk, control, and profit. Problems of business organization are problems in the allocation of these elements among the parties to the enterprise. The law of business organization (agency, partnerships, corporations) is principally concerned with (1) defining the area within which parties are free to allocate risk, control, and profit as they wish, and (2) prescribing the allocation of these elements in the absence of express agreement.

I shall be interpreting the general problem of corporate legislation as a problem in regulating the allocation of these elements of enterprise so as to promote responsibility of investment and management. In the simplest type of business unit, the unincorporated one-man enterprise, no such problem arises. Risk, control, and profit are concentrated in the 
individual enterpriser. He operates under the general rules of contracts, torts, and property-rules which are backed up by remedial law, including the law against transfers in fraud of creditors. These rules, in effect, assign to the enterpriser (as profit or loss) the consequences of his business decisions. Since he thus takes the consequences, he has an incentive to act responsibly-i.e., to act in the light of reasonable anticipations. To the extent that he does so, his actions are responsible in a broader sense also. Where enterprise is free and enterprisers act responsibly in their own interests, they are led by market disciplines to serve the social interest as well. For our purposes, we need not spell out why this is so, since discussions of the modern corporation invariably assume that individual enterprise has this desirable characteristic. What such discussions question is the relevance of this analysis to the large corporation, with its separation of ownership from control.
It is not only the corporate form of organization, however, which creates problems concerning separation of the elements of enterprise. Such problems arise as soon as the enterprise makes use of employees. Basic rules of agency law deal with these problems and are best understood, it seems to me, as efforts to prevent such separation of risk, control, and profit as would jeopardize responsible management. The rule respondeat superior, always difficult to justify on ordinary tort principles, is understandable as an effort to place the risks of the enterprise upon the enterprise, to require the enterpriser to weigh such risks in making his business calculations. Similarly, the liability of the undisclosed principal, which is hard to explain on contract principles, represents an effort to assure responsibility in the decisions made by the owner of

Continued on page 13 


\section{Katz-Continued from page 3}

a business, to make it impossible for the owner to hide behind an irresponsible agent. This explanation applies also to the common-law liability of secret partners. Furthermore, the rules establishing agents' fiduciary duties and disabilities represent attempts to promote responsible action by agents in the interest of their principals. Again, the rule that agency powers are ordinarily revocable, even when stated to be irrevocable, represents another striking effort to check the irresponsible action which might result from irrevocable separation of risk and control. This interpretation explains also the exception to this rule in the case of powers coupled with an interest or powers given as security. The exception permits one who thus participates in the risks of the enterprise to be given irrevocably a share in its control.

These rules reflect concern lest responsible management be jeopardized by arrangements separating risk, control, and profit. They leave great freedom, however, for the allocation of these elements. For example, one who lends money or sells goods to a partnership may agree to look solely to partnership assets, thus assuming a share of the enterprise risk. A lender may agree to take a share of the profits in lieu of interest, or an employee may do so in lieu of fixed salary. They thus become participants in both the profits and the risks of the enterprise, but without sharing the liability of partners. The variety of these voluntary arrangements for sharing risk, control, and profit is enormous. As already indicated, a primary function of the law of business organization is the setting of limits to the possible variations. When the corporate form of organization is made available by statute, the principal legislative question is whether there are special threats to irresponsibility inherent in the corporate form which require special restraints on the freedom to allocate risk, control, and profit. "Philosophies" of corporate statutes reflect divergent answers to this question. Some of these theories will first be stated briefly; in the next part, representative statutory provisions will be examined to ascertain the relative influence of the various theories; and then we should be in a position to consider whether there is a dominant philosophy of the "new look."

1. The first contemporary theory which I shall consider is the theory that a corporation statute should be merely an "enabling act." Under this theory, the privilege of incorporation with "limited liability" should be made freely available, and promoters should have freedom in defining the scope of the enterprise and in allocating risk, control, and profit through the corporation's security structure. This theory prescribes also that relatively unhampered procedures should be available to meet changing conditions by effecting changes in corporate purpeses and security structures.

No special conditions on the use of the corporate form are deemed necessary. This theory implies that decisions for commitment of funds are the individual responsibility of the investor or lender, protected, however, by the law of deceit. Adherence to the agreed allocation of risks is deemed adequately assured by the rules of contracts and fraudulent conveyances; management loyalty is adequately promoted by the rules concerning fiduciary duties and disabilities. This theory reflects also a skepticism as to the effectiveness of protective devices suggested by alternative theories. It is feared also that incomplete legislative protections may result in relaxation of individual efforts at self-protection, efforts which are deemed indispensable if investment decisions are to be responsibly made.

Advocates of the "enabling act" theory reject the notion that a ccrporation statute should deal with the problem of possible monopoly. This theory, therefore, calls for no limitations of size, duration, purposes, or general powers."

The "enabling act" theory does not mean that an adequate corporation statute can be simple and brief. To serve effectively as an enabling act, it must make its grants of power and its authorized procedures sufficiently detailed to minimize doubts, including doubts which might arise from previous statutes and their judicial interpretation.

2. The second theory, like the first, is grounded on the premise that the social interest is best served through responsible individual decisions in the furtherance of individual interests. The second, however, reflects a belief that for corporate organization, the basic common-law doctrines of contracts, torts, and agency are inadequate to assure responsible individual decision, that these doctrines should be elaborated and supplemented at various points to make it less likely that agreements as to division of risk, control, and profit may be inadvisedly made or ineffectually implemented.

For example, to provide a setting for responsible in- 
dividual decision, a corpcration statute may include detailed provisions as to the relative rights of creditors and shareholders, and of holders of different classes of shares-provisions which leave the parties free to determine these rights, but which formalize the way in which the determination must be made and which provide rules applicable in the absence of contrary determination by the parties. A statute drawn on this theory might spell out the application of the law of deceit in the corporation setting. It might go further and relieve lenders and investors of the burden of asking the appropriate questions, creating affirmative duties of disclosure in order to make it more probable that decisions as to commitment of funds, exercise of voting rights, etc. will be responsibly made. Such a statute might also codify other general rules in their particular application to corporate organization, such as the rules prescribing fiduciary standards of loyalty and prohibiting transfers in fraud of credi- tors. In such codification, the rules might be strengthened to block evasion opportunities peculiar to the corporate situation. In short, the second theory still looks to individual decisions made with responsibility, but it advocates the creation of a statutory setting fostering such responsibilty.

3. The third theory prescribes a more drastic remedy, lest risks be inadvertently assumed and powers inadvisedly exercised. It prescribes restrictions on the freedom of the parties to allocate risk, control, and profit by contract. It conceives the task of the legislature as including that of identifying particular types of allocation which are deemed to jeopardize responsible investment and management. For example, the statutes might outlaw nonvoting stock, prescribe a specified margin of safety for creditors, or require more than a simple majority vote for various corporate readjustments.

A point should be added which is applicable to both 
the second and third theories. Their purpose in attempting to check irresponsible enterprise may be not only to protect the investors and creditors directly involved, but also to reduce the likelihood of financial catastrophes which might destroy the climate of reasonable confidence which business enterprise requires. ${ }^{3}$ But whichever may be the dominant motive, the statutes are designed to promote responsible decisions in the interests of investors and creditors. Since the third theory attempts to do this by limiting the area of permissible arrangements, it may fairly be called a "paternal responsibility" theory.

4. The fourth theory is a theory of "social responsibility." Its adherents disparage the foregoing theories as all but irrelevant to the large corporation with its wide dispersion of ownership among inactive stockholders. It is asserted that management neither can nor should be made wholly responsible to stockholders. Absentee owners who have abdicated control have no ethical basis for a claim that the enterprise be conducted to maximize their return. Furthermore, in many industries, so large a fraction of the business is said to be concentrated in a few large corporations that consumers are inadequately protected by market competition. Similarly, where a single plant employs a large fraction of the labor force of the locality, it is argued that alternate employment opportunities furnish inadequate protection against management decisions to reduce operations or to relocate. It is urged that corporate managers should be under no obligation to maximize profit, but should have a wider responsibility; that they should exercise corporate powers in the interest not only of shareholders, but also of employees, customers, and the "general public." While this theory has been much discussed by philosophers of corporation law, it has almost no reflection in the actual statutes. The one exception is the wide adoption of provisions authorizing corporate gifts to charity. Professor Berle considers the charitable-gift statutes as showing the direction of a "20th Century Capitalist Revolution." "We shall consider other statutory changes which a "social responsibility" theory might support after we have reviewed the way in which midcentury statutes deal with a representative group of problems and after we have attempted to measure the influence of the first three theories.

\section{II}

\section{Creditors' margin of safety}

Nineteenth-century corporation statutes embodied in various ways the concept of a capital fund, or margin of safety, for creditors as a substitute for the personal liability of shareholders. The amount of the margin was the par value of the shares issued. The margin requirement was implemented, in varying degrees of effectiveness, by provisicns making subscribers liable for the full amcunt of the par value and protecting this "capital" against impairment through dividends or purchase of outstanding shares. Some of the statutes prescribed a maximum ratio of debt to stock investment, but these provisions wore gradually eliminated and the amount of the crediters' margin left to the will of the incorporators, except for a purely nominal flat minimum. American statutes were, thus, similar to the British Companies Act which W. S. Gilbert lampooned in Utopia, Ltd. According to Gilbert, the statute required of incorporators nothing more than "a public declaration to what extent they mean to pay their debts,"

The American statutes often left serious gaps in the implementation of the margin-of-safety concept. There were sometimes no teeth in the requirement that the capital be paid in, and provisions as to maintenance of capital were commonly incomplete. Of more importance, there were often provisions authorizing reduction of capital without any restriction for protection of existing creditors such as the British requirement of court approval. Authorization of no-par value shares introduced further complexities and doubts. While most of the statutes probably left some place for "stockwatering" liability on no-par value shares, it was doubtful whether the shareholders were required to underwrite the valuation of the entire consideration for their shares or only the portion labeled "stated capital," excluding any amount allocated to "paid-in surplus." This became an important question as to par value shares also with the advent of the current practice of issuing shares with an arbitrarily low par value and a large paid-in surplus.

Following the Model Act as revised in 1955, "several recent statutes have cleared up the confusion as to paid-in surplus. This has been accomplished by re- 
quiring that the consideration for shares, whether par or no-par value, shall be fixed in dollars and by imposing shareholders' liability in terms not of par or stated value, but of the full consideration fixed for the shares (subject to good faith valuation of property transferred in payment). The same statutes, however, often leave creditors without protection against distributions in "partial liquidation," even to the extent of the stated capital. ${ }^{6}$ The extension or clarification of stock-watering liability in these statutes cannot, therefore, be interpreted as an implementation of the margin-of-safety notion, but merely as an effort to check the obtaining of credit through an intentionally misleading balance sheet.

As already suggested, twentieth-century statutes have often permitted formal reduction of capital without protection of existing creditors. Several recent statutes, following the Model Act, have abolished even the necessity of formal reduction and have authorized dividends out of stated capital in partial liquidation if the articles so provide or if shareholder vote is secured. ${ }^{i}$ The limit to such distribution is reached only at the point of insolvency, which is usually defined in recent statutes as an inability to pay debts as they mature in the usual course of business.

Some of the recent statutes, however, retain and revitalize the margin-of-safety concept. Thus, neither Texas nor North Carolina authorizes distributions directly "out of" stated capital, and both put restraints upon distribution of surplus created by reduction of stated capital. Texas dramatically departs from the Model Act by providing that distributions of reduction surplus shall make directors liable to creditors existing at the time of the reduction in the event of later insolvency. ${ }^{8}$ North Carolina requires that any distribution of capital surplus (including reduction surplus) must leave assets at least twice the amount of the debts. ${ }^{9}$ Both of these statutes appear designed to block distributions which would subject creditors to risks which they might not reasonably anticipate. The Texas provision establishes a limit to creditors' risks in terms of stated capital, but the stated capital may be fixed at an arbitrary minimum. The North Carolina provision cannot be reduced to nominal effect, since it covers not only stated capital, but also capital surplus; the margin originally fixed may be reduced, however, so long as there remains a margin of 100 per cent over debts. None of the statutes contains any substantial requirement of original junior investment.

In this field, therefore, none of the statutes reflects the "paternal responsibility" theory, as do the Public Utility Holding Company Act and chapter ten of the Bankruptcy Act, with their control of debt-equity ratios. ${ }^{10}$ What the recent statutes do, in varying degrees, is to protect a margin once established or pur- ported to have been established. They thus illustrate my second theory, clarifying the original agreement or representation as to risk and providing relief by adapting general principles of contracts or deceit. But since most of the statutes take few steps in this direction, they illustrate basically the first or "enabling act" theory, leaving it to creditors to make their own bargains for the limitation of their risk. As a result, elaborate covenants restricting dividends and other distributions and share purchases are now common features not only of bond and debenture indentures, but also of other types of agreements for extension of credit.

\section{Promotion and security flotation}

Apart from statute, courts have imposed upon ccrporate promoters duties beyond those established by the common law of deceit. Promotors have been held to be fiduciaries subject to an affirmative duty of disclosure, for breach of which the corporation may, in certain situations, recover. But it has been open to the promoter to avoid this result by having all the shares issued initially to himself, with sales to the public made by him rather than by the corporation. In this situation, the promoter is free from common-law liability, unless his conduct amounted to deceit. It is usually not difficult to arrange the promotion transactions in the form which thus minimizes risk of liability.

The recent North Carolina statute is unique in closing this loophole. It includes within its definition of "watered shares" (which are made subject to cancellation or assessment) all shares issued to promoters for overvalued property which unfairly dilute the holdings of other shareholders to whom adequate disclosure has not been made. ${ }^{11}$ Thus, in North Carolina, corporation lawyers can no longer defeat the requirement of disclosure by mere technical arrangement of prcmotion transactions.

Draftsmen of other ccrporation statutes have ignored this problem, perhaps because the separate securities acts or "blue sky" laws provide statutory remedies for purchasers of stock. While these statutes are beyond the scope of this symposium, one point may be noted as to how they illustrate the general theories considered in this paper. This is the familiar contrast between the Federal Securities Act of 1933 and the typical state securities law. The federal act, like the North Carolina promoters' profit provision, is a disclosure act; it thus illustrates my second theory, supplementing and reinforcing the law of deceit in order to promote responsible investment. The state securities acts, on the other hand, usually vest in their administrators discretionary power to halt the sale of securities which are deemed to be "inequitable" or which would "tend to work a fraud." For example, under 
these statutes, maximum selling commissions are often established and particular types of financing arrangements are forbidden. Such provisions illustrate, or course, my third, or "paternal responsibility," theory. Even the SEC, furthermore, exercises influence on the terms of security flotations not only through its disclosure requirements, but also by conditioning the exercise of its discretionary power to accelerate registration upon compliance with certain approved standards. ${ }^{12}$

\section{Fiduciary duties and their enforcement}

Application to corporate officers and directors of the agency standards of fiduciary loyalty has generally been accomplished without the aid of statute. Legislation in this field, however, has been on the increase. A few of the statutory provisions have tightened fiduciary standards. Several recent statutes have flatly forbidden all loans to officers and directors. A few have facilitated derivative suits by subjecting nonresident directors to jurisdiction on constructive service. In general, however, there has been little effort in state legislation to keep corporate fiduciaries away from temptation. State legislatures have not followed the federal lead with devices like the recapture of profits from "short trading ${ }^{13}$ or in extending fiduciary duties to dealings with individual shareholders. ${ }^{14}$ Some of the recent statutes may have actually reduced the force of the common-law rules. For example, many state courts have declared that transactions authorized through the vote of a director adversely interested are voidable regardless of fairness. The North Carolina statute, however, provides that a transaction shall not be set aside if proved to have been "just and reasonable to the corporation" at the time it was approved. ${ }^{15}$ Several recent statutes, furthermore, authorize the fixing of executive compensation without a disinterested majority in the board and without shareholder ratification. There have been several provisions authorizing stock option plans for executives. Some of these have followed the Model Act optional provision which requires approval by shareholders. ${ }^{16}$

With respect to enforcement of fiduciary duties through shareholders' derivative suits, recent statutes are primarily concerned with the "strike suit" problem. They continue the trend toward the rule disqualifying plaintiffs who were not shareholders at the time of the alleged wrong. The recent statutes typically authorize indemnification of defendant directors for litigation expenses in cases where the litigation is settled as well as where defendants are judicially exonerated. Most of these provisions follow the Model Act in rejecting both the California requirement of court approval and the New York requirement of reporting to shareholders. ${ }^{17}$ The North Carolina statute, however, does require court approval. ${ }^{18}$
A few of the recent statutes include provisions for posting by shareholder-plaintiffs of security for litigation expenses of defendants. Wisconsin gives defendants a right to such security from plaintiffs holding less than three per cent of the shares of any class. ${ }^{19}$ North Dakota enacts the Model Act optional provision under which no security may be required of plaintifts whose holdings exceed $\$ 25,000$ in market value. ${ }^{20}$ A companion provision authorizes the court, at the end of any derivative suit, to require plaintiffs to pay defendants' expenses if the court finds that the action was brought without reasonable cause. ${ }^{21}$

On balance, the recent legislation concerning fiduciary duties illustrates the "enabling act" theory, since its major concern has been lest application of commonlaw doctrines should be unduly restrictive of corporate management.

\section{Election of directors}

Most American statutes have not regulated the allocation of voting rights as a means of promoting management responsibility to those bearing the ultimate risk. To be sure, provisions for removal of directors, with or without cause, are increasingly common. Removal action, however, can be taken only by shareholders with voting rights, and all of the recent statutes permit denial of voting rights to any class or classes of shares. The statutes have no general requirement of "equitable" distribution of voting power like those of the Holding Company Act and chapter ten of the Bankruptcy Act."- Nonvoting common shares are permissible, and exclusive voting control may thus apparently be vested in a small, closely-held class of "management shares" representing only nominal investment. Furthermore, express authorization of voting trusts is now customary, usually limited to ten 
years' duration, but without time limit under the Wisconsin statute. ${ }^{23}$ The importance of the statutory freedom to separate risk and voting control is somewhat reduced, however, by the fact that the New York Stock Exchange refuses to list nonvoting common shares. Mandatory cumulative voting to permit minority representation is provided in the Ohio ${ }^{24}$ and North Carolina ${ }^{25}$ statutes and in the original Model Act. ${ }^{26}$ These statutes reflect a belief that, on balance, responsible management is promoted by providing this channel of criticism, notwithstanding the dangers of dissension within the board. Most of the states following the Model Act have chosen the alternative provision for permissive cumulative voting. ${ }^{2 \tau}$ Massachusetts, however, has recently repealed its permissive provision and now has no authorization. ${ }^{28}$

\section{Preferred shares}

“... preferred stockholders are not-like sailors or idiots or infants-wards of the judiciary." ${ }^{29}$ This dictum of Judge Frank was pronounced in a case involving "noncumulative" preferred stock. Paraphrasing Gertrude Stein, he insisted: “. . . a contract is a contract is a contract." ${ }^{\prime \prime}$ To what extent, we may ask, do preferred stock provisions of midcentury corporation statutes reflect a similar philosophy? To what extent, on the other hand, have preferred stockholders become wards of the legislature? The North Carolina statute has gone farthest in the latter direction. I shall summarize the principal provisions which support this statement and indicate some of the contrasts afforded by other statutes.

Before this is done, however, it should be noted that the North Carolina statute has also some unique provisions designed to obviate troublesome problems of interpretation without limiting contractual freedom. It is provided that preferred shareholders are excluded from participating beyond their stated preferences (dividend and liquidation), unless the language clearly indicates the contrary. Similarly, the amount of any dividend arrearage is to be added to the stated liquidation preference, unless this result is clearly inconsistent with the charter wording. ${ }^{31}$

None of the state statutes approaches the kind of standardization of preferred-stock provisions and regulation of capital structures which the Securities \& Exchange Commission has developed under the Public Utility Holding Company Act. No state requires, as do these SEC regulations, that holders of preferred stock be empowered to elect a majority of the directors when dividends are in arrears; nor do the state statutes regulate the ratio of preferred to common stock investment. ${ }^{32}$ The North Carolina statute however, does provide that, regardless of charter language, noncumulative preferred shareholders shall be entitled to a "dividend credit" to the extent that their dividends are earned but not declared in any year. ${ }^{3.3}$

Another unique provision of this statute enables preferred shareholders to protect themselves against distributions of capital surplus to common shareholders in partial liquidation. Such a distribution requires a majority vote of each class. ${ }^{34}$ (There is no corresponding restriction, however, on the use of the same funds to purchase common shares.) The statute also contains a general prohibition of dividends and purchases of shares if the action would reduce net assets to an amount below the aggregate liquidation preferences of preferred shareholders. ${ }^{3 i}$

Contemporary statutes deal in increasing detail with changes in the position of preferred shareholders through charter amendment, merger, etc. They typically contain express authority for cancellation of arrearages but require approval by preferred shareholders voting as a class, even if the class has no voting rights in elections of directors. Following Delaware, North Carolina requires only a simple majority of the class, ${ }^{36}$ while the Model Act requires two-thirds. ${ }^{37}$ The North Carolina statute adds a caveat: "No inference shall be drawn from the broad power of amendment conferred by this chapter that an exercise of that power in a particular case is fair and equitable." ${ }^{3 *}$ Contrary to the Model Act, appraisal rights are given to dissenting preferred shareholders in certain cases 
of charter amendment as well as merger ${ }^{39}$ and an appraisal floor is set at two-thirds of the liquidation preference if junior shares participate in the plan without contribution. ${ }^{\text {"1 }}$

The North Carolina draftsmen removed one of the sources of the pressure sometimes exerted upon preferred shareholders to agree to a reduction of their rights. In states where dividends out of current earnings are forbidden when capital is impaired payment of preferred dividends may require a reduction of capital, which common shareholders are in a position to block. The North Carolina statute not only permits payment of preferred dividends out of current profits when capital is impaired, but also makes this provision override any charter limitation to the contrary. ${ }^{41}$ Purchases of preferred shares at prices depressed by suspension of dividends are somewhat restricted by the requirement of prior notice of intention to make such purchases.." Under the Texas statute, no shares may be purchased when dividends are in arrears. ${ }^{43}$

Most of the recent statutes have no similar provisions restricting the allocation of risk, control, and profit among holders of various classes of shares. They leave it to investors in preferred shares (as they do to creditors) to bargain out acceptable protective pro. visions.

\section{III}

The foregoing summary makes clear that the recent statutes reflect, in general, an "enabling act" theory, more or less modified by the theory that corporation statutes while assuring freedom of contract, should reinforce in various ways the responsibility of individual decisions; and the theory that freedom of the parties should be limited in order that the results of responsible freedom may more nearly be approximated. Only the North Carolina statute has gone very far in applying the latter theories; it thus has a kind of "new look" which is conspicuous in the parade of new statutes.

Apart from this almost unique design, what is there in the other recent statutes, particularly those patterned after the Model Act, which justifies the term "new look"? It is sometimes suggested that the novelty of design is to be appreciated by contrasting the Delaware General Corporation Law. A principal draftsman of the Model Act reported the opinion of the American Bar Association Committee that the Delaware Act is ${ }^{4+}$

poor in sequence and loose in its provisions. . . [ [ It] bids for the corporate business of promoters. It makes little or no effort to protect the rights of investors. Hence, in the opinion of the committee, it was not the type of statute which the committee should present as a model. . . The model act makes use of only one provision of the Delaware statute and that is the provision empowering corporations to indemnify their directors. ...
This quotation seems to me to exaggerate the differences in substance between the Delaware and Model acts. The examples of "loose" Delaware provisions cited in this article are those permitting charter amendment by simple majority and permitting dividends from current earnings notwithstanding a capital deficit. ${ }^{45}$ Neither of these features seems conspicuously "loose"; both are incorporated in the new North Carolina statute, ${ }^{46}$ the draftsmen of which were certainly solicitous of the interests of investors. There are, of course, other provisions of the Delaware statute which are open to criticism, such as the authorization of dividends out of capital surplus with no requirement that the source be identified. ${ }^{4 i}$

The most important contrast between the Delaware and Model acts is that indicated by the statement that the Delaware statute is "poor in sequence." At the time the Model Act was prepared, the Delaware Act was exceedingly difficult to use because of its lack of convenient arrangement and its long, involved sentences. In the revised Delaware Code of 1953, the General Corporation Law was improved by breaking Continued on page 22 


\section{Katz--}

\section{Continued from page 19}

up and rearrangement of sections, but unwieldy sentence structure still predominates. The Model Act has, indeed, a new look: it is vastly easier on the eyes. (Some of my friends out here in the provinces say that it's the difference between Chicago and New York styles of corporate draftsmanship.)

\section{IV}

We have seen that a more or less unmodified "enabling act" philosophy is dominant in most of the recent corporation statutes, as it is in the Delaware statute. It is a curious fact, hcwever, that this philosophy is seldom articulated and almost never defended with confident vigor. Its objective-responsible management in the interests of shareliclders-has been under attack for over a generation. The attack has come from many sources-from social philosophers and theologians, from economists and law teachers and business executives.

This movement began with Thorstein Veblen, who caustically depicted the mcdern corporation, with its inactive stockholders, as a prime example of "absentee ownership." +8 Of greater importance, perhaps, were the pronouncements of corporation executives in the twenties, heralding a new orientation of m-nagement loyalty. Henry Ford, in trying to defend his limited dividends against minority stockholder attack, disclaimed any intention to maximize profits and proposed, instead, to reduce prices for the benefit of car buyers and to create more jobs. While the Supreme Court of Michigan flatly rejected this view of corporate purposes, ${ }^{49}$ other leading executives espoused the same philosophy. Owen D. Young wrote that he considered himself a trustee not merely for stockholders, but for the corporate "institution"-i.e., for stockholders, employees, customers, and the general public. ${ }^{50}$

In 1932, Adolf A. Berle and Gardiner C. Means, in The Modern Corporation and Private Property, gave strong support to this idea, and their work was widely hailed as a contribution of outstanding importance. Tracing the extent of the separation of ownership from control in the modern corporation, they challenged the ethical claim of the inactive investor to the residual profits of industry. They declared that ${ }^{\text {i1 }}$

it seems almost essential if the corporate system is to survive,that the "control" of the great corporations should develop into a purely neutral technocracy, balancing a variety of claims by various groups in the community and assigning to each a portion of the income stream on the basis of public policy rather than private cupidity.

True, when Professor E. Merrick Dodd called for legal recognition of the new principle of wider respon- 
sibility, Professor Berle suggested caution. ${ }^{52}$ In rejoinder, Dodd insisted that a principle of "vicarious acquisitiveness" has little ethical or emotional appeal either to managers or to the general public. For Dodd, the principle of trusteeship for absentee investors presented a melancholy dilemma: "Abandon it as yet, we dare not-enforce it with more than moderate success, it is to be feared we cannot."

I have said that the "social responsibility" philosophy has had almost no influence upon recent statutes. The one exception is the now popular authorization of corporate gifts to charity. Even before these statutes, of course, many types of donations were defensible as means of creating consumer or employee goodwill. The recent statutes, however, cover much broader ground. The pressure for corporate giving was a result of tax laws which made it increasingly difficult to finance charities through individual gifts. Congress was induced to provide a limited tax deduction for corporate donations. ${ }^{54}$ One cannot dismiss the state statutes, however, as merely dealing with a tax problem. They do represent a limited acceptance of the social responsibility theory, as the New Jersey court recognized in the leading case. ${ }^{55}$ Many of the recent statutes, furthermore, have set no limits upon corporate gifts, either in terms of amount or of shareholder approval. Ohio has recently repealed its previous limitations. ${ }^{56}$

As already noted, Professor Berle considers that these statutes are signs of a corporate revolution. Magnanimously, he now concedes victory to Professor Dodd in their 1932 controversy over "To Whom Are Corporate Managers Trustees?"57 I find it hard to believe that the charitable-gift statutes and practices will prove to be forerunners of a major change. Under the traditional view, risk-taking investment is typically made in the hope not only of cash dividends, but also of appreciation reflected in stock prices and often "realized" through stock dividends and splits with gradually increasing total cash distributions. I see no reason to think that this concept of common stock is soon to be replaced by a concept under which the expectation of stockholders will be limited, like that of holders of perpetual debentures, with no claim upon residual profits. Corporate giving may increase, but it is unlikely that whatever profits are left after "reasonable dividends" will come to be regarded as at the disposal of the directors in accordance with their views of public welfare.

Apart from these provisions for charitable contributions, the new concept of social responsibility has had almost no elaboration. It is not merely that the theory has had no further influence on the actual statutes, but in a quarter of a century, neither the originators of this philosophy nor their disciples have sketched with any detail or persuasiveness the lines of possible practical application. And the few suggestions which have been made justify skepticism as to the seminal quality of the new theory.

In 1954, George Goyder, an English businessman, published The Future of Private Enterprise-A Study in Responsibility. In his view, ${ }^{58}$

The weakness of Company Law at present is that the directors are without legal guidance as to their responsibilities to the workers, the consumers or the community. ... What is wanted is a General Objects Clause, declaring management responsibility for "fair and reasonable prices," "regular dividends," "stable employment under good conditions so far as possible," etc. Once defined, the legal responsibilities ... of the directors, can be made actionable in a court of law, ...

Nothing could be simpler; but the history of utility regulation and of emergency price and wage controls is soberingly relevant. To say the least, standards of "fair" prices and wages are hard to come by, and few lawyers can be optimistic about the litigation process as a mode of developing such standards.

More cautious is the approach of Howard R. Bowen in Social Responsibility of the Businessman, part of a study commissioned by the Federal Council of Churches and published in 195.3. Dr. Bowen endorses the "social responsibility" concept, but, as an economist, he recognizes that businessmen ${ }^{59}$

are often not in a good position to know how they can best serve society, and their decisions based on the service motive may often hit wide of the target. . . They need short-cut methods of reaching decisions that do not involve all the complexities of relating every individual action to the social interest. The price system provides that short-cut method. With all its imperfections, it is a marvelous device for registering 
social valuations and thus providing a system of easily recognizable signals by which individuals can reconcile their own self-interest and the social interest. . . . [Thus, the businessman should] rely primarily on profit as his guide. . . [ [ He should depart from this guide only when it leads him toward] restrictive monopoly, exploitation, fraud, misrepresentation, political bribery, waste of natural resources, economic insecurity, etc.

Here, again, these terms offer little guidance to the conscientious director (except as to misrepresentation and other conduct forbidden by law).

In general, one may question the extent to which socially responsible deliberation would actually lead management to decisions different from those indicated by long-range profit considerations. For example, concern for employee goodwill might well cause management to seek ways to cushion the effects of production cut-backs, automation, plant relocation, etc. If advocates of "social responsibility" would have management go much farther in maintaining unprofitable operations, it is by no means clear that such action would be socially responsible. And with respect to price policy, however seriously management might regard its social responsibility, perhaps the influences operating to further the social interest would still be principally those resulting from competition among products and producers for consumers' spending. ${ }^{60}$ In any event, management must be concerned with the extent to which the new concept of corporate responsibility may influence behavior of consumers or employees. If public opinion comes to expect corporations to assume some new responsibility, this is a fact which profit-conscious management can not ignore. 
Another "reform" proposed in the name of social responsibility is the abolition of shareholder voting rights. This is a measure advocated by Peter F. Drucker after a period as official philosopher-in-residence at General Motors. According to Drucker, "there is absolutely nothing in the nature of investment that either requires or justifies ownership rights, that is rights of control"; voting power should be "vested in perpetuity in the Board of Directors," who would elect to their number "representatives" of investors, management, and the "plant community." ${ }^{11}$ Drucker regards this as merely legalizing the disfranchisement already existing in fact. Criticizing this position, Lloyd K. Garrison expressed belief that ${ }^{62}$

upon close examination it will be found that even in the case of the great corporations whose securities are widely distributed and largely voted by management proxies, effective control over many basic policy decisions is lodged in some stockholder group-perhaps in a very small minority, but in an effective one; ...
Drucker brushes aside or disapproves not only the influence of particular stockholders, but also the general influence arising from the possibility of organized opposition. But after recent examples of proxy warfare, it would be rash to assert that these possibilities exert no wholesome stimulus or restraint upon management. When poor management is reflected in reduced earnings, the resulting decline in stock prices may create attractive opportunities to accumulate shares in a bid for control. To be sure, the stock market is not an ideal mechanism for the discipline of management. But, whatever may be the dangers from corporation "raiders," it is at least doubtful that management responsibility would be improved by making it impossible to acquire working control through purchases of stock. ${ }^{63}$

The vitality of the "social responsibility" theory is not to be measured by the limited enthusiasm which these typical proposals have engendered. The theory 
is important as a perennial insistence that there just must be some new way of disciplining corporate profitseeking. Expressing his disappointment with Bowen's report, the Rev. F. Ernest Johnson asked almost wearily "Is it not possible to devise instruments of at more authentic corporate responsibility?" 64 But the prospect of a break-through on this front is not encouraging, for what is demanded is a contrivance which would operate neither through individual responsibility and competitive markets nor through political controls.

The new philosophy has thus far succeeded in producing only an unresolved discontent with existing corporation law. It has obscured the values served by the older philosophies and the fact that these philosephies also can lay claim to the "social responsibility" label. Perhaps corporation law critics should keep straining to catch Professor Berle's vision of "The Modern Corporation and the City of God." 65 But in the meantime, we need not be defensive about the statutes of North Carolina and Texas-or even those of Illinois and Delaware. None of them, to be sure, is a model ordinance for the City of God. But the corporate organizations they make possible are institutions not inappropriate for economic activity in the Earthly City.

\section{FOOTNOTES}

'Harris, The Model Business Corporation Act-Invitation to Irresponsibility?, 50 Nw. U. L. Rev. 1 (1955).

Recent corporation statutes show almost no traces of the general restrictive theory of which the classical statement is the opinion of Mr. Justice Brandeis in Louis K. Liggett Co. v. Lee, 288 U. S. 517,541 ( 1933 ). 
"Examples of this theme can be found in the writings of Jerome N. Frank and William O. Douglas. See dissenting opinion of Commissioner Frank in In the Matter of The North American Company, 4 S.E.C. 434, 462 (1939); William O. Douglas, Democracy and Finance (1940).

'Adolf A. Berle, Jr., The 20th Century Capitalist Revolution 164, 168 et seq. (1954).

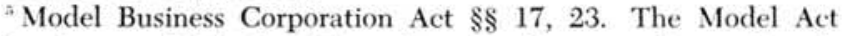
has been published as Committee on Corporate Laws, American Bar Association, Model Business Corporation Act (1953). The 1955 revisions and optional sections appear in a supplemental leaflet. Id., Revisions and Optional Sections (1955). ${ }^{8} \mathrm{Cf}$. Model Business Corporation Act $\$ 41$.

"Ibid.

Tex. Bus. Corp. Act art. $2.41 \mathrm{~A}(6)$ (1956).

' N. C. Gen. Stat. $\$ 55-50$ (e) (3) (Supp. 1955).

${ }^{10} 49$ Stat. 815 (1935), 15 U.S.C. $\$ 79 \mathrm{~g}$ (1952); 52 Stat. 895, 897 (1938), 11 U.S.C. $\$ \$ 616,621$ (1952).

"N. C. Gen. Stat. $\$ 55-53$ (Supp. 1955).

${ }^{12}$ Note to SEC Rule 460, Securities Act Release No. 3791, May $28,1957$.

${ }^{13}$ Cf. Securities Exchange Act of 1934, $\S 16$ (b), 48 Stat. 896, 15 U.S.C. $\$ 78 \mathrm{p}(\mathrm{b})$ (1952).
"Cf. SEC Rule X-10B-5, 17 C.F.R. \$ 240-106-5 (1949).

${ }^{15}$ N. C. Gen. Stat. $\$ 55-30$ (b) (3) (Supp. 1955).

${ }^{16} \mathrm{Cf}$. Model Business Corporation Act $\$ 18 \mathrm{~A}$.

${ }^{17}$ Cf. id. $\$ 4(0)$. But see Cal. Corp. Code $\$ 830$ : N.Y. Gen. Corp. Law $\$ 63$.

"N.C. Gen. Stat. \$ 55-21 (a) (2) (Supp. 1955 ).

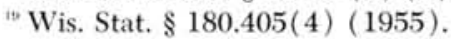

${ }^{\prime \prime}$ N.D. Laws 1957, c. 102, $\$ 44: c f$. Model Business Corporation Act $\S 43 \mathrm{~A}$.

"I bid.

${ }^{2}$ Cf. note 10 supra.

Wis. Stat. $\$ 180.27$ ( 1955 ).

"Ohio Rev. Code Ann. $\$ 1701.55$ (Page Supp. 1956).

$=$ N.C. Gen. Stat. \$ 55-67(c) (Supp. 1955).

${ }^{34}$ Model Business Corporation Act $\$ 31$.

$=\mathrm{Cf}$. id. alternative $\$ 31$.

" Mass. Laws 1956, c. 375 .

${ }^{9}$ Guttmann v. Illinois Central R. Co., 189 F.2d 927, 930 (2d Cir. 1951).

${ }^{50}$ Ibid.

${ }^{3:}$ N.C. Gen. Stat. $\S 55-40$ (b) (Supp. 1955),

${ }^{3}$ Cf. 49 Stat. 815 (1935), 15 U.S.C. $\$ 79 \mathrm{~g}$ (1952). See also Public Utilities Holding Company Act Release No. 13106, 
Feb. 16, 1956.

N.C. Gen. Stat. \& 55-40(c) (Supp. 1955).

Id. $\$ 55-50$ (c) (1).

$=I d . \$ 55-50(\mathrm{c})(3)$.

${ }^{36}$ Id. $\$ 55-100$ (b) (3); cf. Del. Code Ann. tit. 8, $\$ 242$ (1953).

जT Model Business Corporation Act \$ 54(c).

$=$ N.C. Gen. Stat. \$ 55-99(a) (Supp. 1955).

Id. $\$ 55-101$ (b). But cf. Model Business Corporation Act $\$ \$ 71,74$.

"N.C. Gen. Stat. \$ 55-113(c) (Supp. 1955).

"Id. $\$ 55-50(\mathrm{~b})$.

${ }^{\prime 2} I d . \$ 55-52(\mathrm{f})$.

${ }^{15}$ Tex. Bus. Corp. Act art. 2.03C (1956).

"Campbell, The Model Business Corporation Act, Business Lawyer, July 1956, pp. 98, 100-01.

${ }^{45}$ Del. Code Ann. tit. 8, $\$ \$ 242,170$ (1953).

${ }^{40}$ N.C. Gen. Stat. $\$ \$ 55-101,55-50$ (Supp. 1955).

${ }^{4}$ Del. Code Ann. tit. 8, $\$ 170$ (1953).

"Thorstein Veblen, Absentee Ownership and Business Enterprise in Recent Times $c$. V. (1923).

"Dodge v. Ford Motor Co., 204 Mich. 459, 505-06, 170 N.W. 668, 683-84 (1919).

at Quoted in John H. Sears, The New Place of the Stockholder 208-10 (1929).

P. 356.

Dodd, For Whom Are Corporate Managers Trustees? 45 Harv. L. Rev. 1145 (1932); Berle, For Whom Corporate Managers Are Trustees, $\mathrm{id}$. at 1365.

is Dodd, Is Effective Enforcement of Fiduciary Duties of Corporate Managers Practicable? 2 U. Chi. L. Rev. 194, 207 (1935). "Int. Rev. Code of 1954, $\$ 170$ (b) (2).

A. P. Smith Mfg. Co. v. Barlow, 13 N.J. 145, 98 A.2d 581 (1953).

Ohio Rev. Code Ann. \& 1701.13(D) (Page Supp. 1956). Cf. id., $\$ 1702.26$ (Page 1953).

Berle, op. cit. supra note 4, at 169.

is Pp. 92-93.

${ }^{5}$ Pp. $144,146$.

${ }^{\infty}{ }^{\infty}$ In any event, one would not be unduly skeptical of moral restraints if he hesitated to follow social responsibility enthusiasts when they urge radical relaxation of antitrust laws. See David E. Lilienthal, Big Business: A New Era (1953). ${ }^{61}$ Peter F. Drucker, The New Society 340, 342 (1950). See also Peter F. Drucker, Concept of the Corporation (1946). New York University School of Law, Social Meaning of Legal Concepts No. 3, The Powers and Duties of Corporate Management 259 ( 1950 ).

${ }^{47}$ See Director, The Modern Corporation and the Control of Property, in University of Chicago Law School Conference on Corporation Law and Finance 17 (1951).

" Commentary, pt. 2, Howard R. Bowen, Social Responsibilities of the Businessman 254 (1953). Cf. Stephen F. Bayne, The Optional God 48-51 (1953).

this This is the title of the final chapter of Berle, op. cit. supra note 4 . 